УДК 373. 3(091)

DOI: https://doi.org/10.35619/iiu.v0i9.132

Бричок Світлана

кандидат педагогічних наук, доцент, доцент кафедри педагогіки початкової освіти

Рівненського державного гуманітарного університету,

м. Рівне, Україна

ORCID: 0000-0001-8508-8395,

e-mail: brychok.zd@gmail.com

Шелюк Галина

викладач кафедри теорії і методики виховання

Рівненського державного гуманітарного університету,

м. Рівне, Україна

ORCID: 0000-0001-7648-3166,

e-mail:galina_rustle@ukr.net

\title{
ЖУРНАЛ «ЗАПАДНО-РУССКАЯ НАЧАЛЬНАЯ ШКОЛА» ЯК ДЖЕРЕЛО ВИВЧЕННЯ ДІЯЛЬНОСТІ РЕГІОНАЛЬНИХ ПОЧАТКОВИХ ШКІЛ ПОЧАТКУ ХХ СТ.
}

\begin{abstract}
Анотація. У статті на основі цілісного аналізу змісту журналу «Западнорусская начальная школа» (1906-1917) доведено, що часопис був своєрідною енциклопедією, навчально-методичним посібником, трибуною обміну досвідом творчих вчителів церковнопарафіяльних шкіл початку $\mathrm{XX}$ ст. У журналі друкувалися документи Св. Синоду, урядові розпорядження, що стосувалися сфери освіти, розпорядження єпархіальних училищних рад і їх роз'яснення, звіти про стан церковнопарафіяльних шкіл західноросійських єпархій, загальні педагогічні й методичні статті, що переважно стосувалися програм початкових і вчительських шкіл; повчальні статті, нариси й розповіді про внутрішне життя школи, про позашкільну діяльність учителів, про участь школярів у богослужіннях, паломництвах, про заняття ремеслами й рукоділлям; матеріали 3 позашкільної освіти, про шкільні бібліотеки, вечірні і недільні класи для дорослих, читання для народу; огляди й рецензії видань 3 педагогіки. У якості додатків друкувалися документи з'їзду училищної ради (1907), звіти про стан церковнопарафіяльних шкіл Київської єпархії (1912-1917).

У публікаціях часопису відображені погляди вчених, письменників, суспільних діячів, учителів на розвиток початкової освіти. Незважаючи на відмінність у підходах до оцінки церковно-шкільної справи й певну упередженість в цих оцінках, публікації журналу містять велику кількість фактичного матеріалу про різноманітні аспекти діяльності початкових шкіл досліджуваного періоду.

Доведено, що журнал «Западно-русская начальная школа» $є$ цінним джерелом вивчення історії початкової освіти початку ХХ ст., інформативною ілюстрацією процесу розвитку регіональної початкової школи в контексті суспільнокультурного життя на українських землях.

Ключові слова: журнал «Западно-русская начальная школа», історикопедагогічне джерело, початкові школи, учитель, церковнопарафіяльні школи.
\end{abstract}


Постановка проблеми. Для вивчення історії початкової освіти, зокрема, особливостей організації навчально-виховного процесу у початковій школі різних історичних періодів, доцільним $€$ звернення до тогочасних періодичних видань як важливих джерел з історії освіти. Наприклад, специфіку діяльності вітчизняних початкових шкіл другої половини XIX - початку XX століття можна відслідкувати за публікаціями часописів «Русская школа», «Киевская старина», «Учитель», «Журнал Министерства народного просвещения», «Вестник воспитания», «Педагогичекий листок», «Народное образование», «Образование», «Русский начальный учитель», «Церковно-приходская школа», «Западно-русская начальная школа», «Законоучитель», «Школьник», «Храм и школа», «Світло», «Вільна українська школа» та ін. Адже періодичні педагогічні видання - «своєрідна «скарбниця» джерел епохи, «сховище» значного масиву фактичного матеріалу для вивчення особливостей розв'язання конкретних проблем у певний історичний період та багатого дослідницького джерела для проведення історико-педагогічних досліджень» (Побірченко, 2010).

Тому мета пропонованої розвідки полягає у здійсненні цілісного аналізу журналу «Западно-русская начальная школа» задля усвідомлення його ролі в історико-педагогічній історіографії та джерелознавстві проблеми вивчення діяльності регіональних початкових шкіл початку XX ст.

Аналіз останніх досліджень із проблеми. Роль педагогічної преси у розвитку теорії і практики освіти досліджували Е. Панасенко (2001), А. Пугач (2008), С. Лобода (2010), Н. Побірченко (2010).

Журнал «Церковно-приходская школа» різноаспектно вивчено нами: С. Бричок (2013), Г. Шелюк (2015).

Відомий сучасний український історик В. Перерва у праці «Церковні школи в Україні (кінець XVIII - поч. XX ст.): забутий світ» (Біла Церква, 2014), здійснюючи історіографічний огляд літератури 3 проблеми діяльності церковних шкіл в Україні, зазначає: «Значно якісніша дисертація вже винятково стосовно історії ЦПШ на Волині належить С. Б. Бричко (напевно, мова йде про дисертацію С. Б. Бричок «Церковнопарафіяльні школи в системі початкової освіти на Волині (друга половина XIX - поч. XX ст.)» (Житомир, 2005) - уточнення наше.). Автор провела значно масштабніші дослідження і залучила досить широку джерельну базу. Хоча певні недоліки притаманні й цій праці. Дисертантка, очевидно, не мала можливості використати матеріали санкт-петербурзького Російського державного історичного архіву, проте в праці є посилання на опубліковані синодальні матеріали. Авторці відомий журнал «Церковноприходская школа», проте в праці немає посилань на його не менш інформативне продовження - часопис «Западнорусская начальная школа»...» (Перерва, 2014).

Викладена теза зумовлює дати певні пояснення. Оскільки територіальні межі дисертації С. Бричок обмежені Волинською губернією, ми не вважали за необхідне залучати публікації журналу «Западно-русская начальная школа» у дослідження. Однак журнал «Западно-русская начальная школа», дійсно, $е$ досить інформативним і на сьогодні практично не дослідженим історикопедагогічним джерелом вивчення діяльності початкових шкіл, що актуалізуе потребу його аналізу в межах пропонованої наукової розвідки.

Виклад основного матеріалу дослідження. Журнал «Западно-русская начальная школа» - щомісячний педагогічний журнал, видавався у Києві 
Київською єпархіальною училищною радою з січня 1906 р. по травень 1917 р. i був продовженням відомого журналу «Церковно-приходская школа», що видавався з серпня 1887 р. і до червня 1906 р. тією ж Київською єпархіальною училищною радою (Троцкий, 2013). Редакторами журналу «Западно-русская начальная школа» були головуючі в училищній раді Уманський єпископ Агапіт (Вишневський; 1906-1908), Чигиринський єпископ Павло (Преображенський; 1908-1910) і Уманський єпископ Димитрій (Вербицький; 1910-1917) (там само).

В основу видання була покладена ідея «дати місцевим педагогічним силам доступ і можливість загального й публічного обговорення теоретичних $\mathrm{i}$ практичних питань народної школи й народного учительства» (Трошин, 1909).

I хоча журнал видавався єпархіальною училищною радою, у центрі його уваги були проблеми не тільки церковнопарафіяльних шкіл, але й народної школи. Редакція журналу вважала за необхідне стверджувати шкільну практику на основах сучасної наукової педагогіки, а не лише релігійної.

Журнал був енциклопедичним за змістом, тому що здійснював й обговорення принципових теоретичних проблем, і розробку широкого спектра питань педагогічної практики, порушував найважливіші проблеми педагогіки як науки. У ньому друкувалися документи Св. Синоду, урядові розпорядження, що стосувалися сфери освіти, розпорядження єпархіальних училищних рад i їх роз'яснення, звіти про стан церковнопарафіяльних шкіл західноросійських єпархій, загальні педагогічні й методичні статті, що переважно стосувалися програм початкових і вчительських шкіл; повчальні статті, нариси й розповіді про внутрішнє життя школи, про позашкільну діяльність учителів, про участь школярів у богослужіннях, паломництвах, про заняття ремеслами й рукоділлям; матеріали з позашкільної освіти, про шкільні бібліотеки, вечірні і недільні класи для дорослих, читання для народу; огляди й рецензії видань 3 педагогіки.

У якості додатків друкувалися документи з’їзду училищної ради (1907), звіти про стан церковнопарафіяльних шкіл Київської єпархії (1912-1917) (Трошин, 1909).

У публікаціях часопису відображені погляди вчених, письменників, суспільних діячів, учителів на розвиток початкової освіти. Незважаючи на відмінність у підходах до оцінки церковно-шкільної справи й певну упередженість в цих оцінках, публікації журналу містять велику кількість фактичного матеріалу про різноманітні аспекти діяльності різних типів навчальних закладів упродовж усього періоду розвитку держави, зокрема й відомства Св. Синоду.

Аналіз ролі журналу «Западно-русская начальная школа» як історикопедагогічного джерела про організацію навчально-виховного процесу початкових шкіл початку минулого століття $є$ особливо важливим, позаяк праці, вміщені на шпальтах журналу, містять багато фактологічного й статистичного матеріалу.

Аналіз публікацій журналу дає змогу простежити реальний стан освітньої справи, тому що кожного року в журналі публікувалися звіти про стан церковнопарафіяльних шкіл за минулий рік. Приміром, у № 2 за 1915 рік видруковано «Отчет о состоянии церковноприходских школ за 1912-1913 учебный год», в якому представлені статистичні дані кількості вчителів 
Київської митрополії та їх педагогічний стаж (Отчет о состоянии церковноприходских школ за 1912-1913 учебный год, 1915).

Матеріали публікацій журналу не тільки демонстрували щиру зацікавленість діячів початкових шкіл у поширенні освіти, їхню самовідданість у цій нелегкій справі, їхні надії й упевненість у необхідності того, що вони робили для народу, але й надавали методичну підтримку, оскільки кожен номер журналу вміщував на своїх сторінках серію статей дидактичного характеру. Приміром, у шостому номері часопису за 1908 рік надруковано статтю відомого просвітителя, педагога К. Сльницького «До питання про викладання педагогіки», у якій автор обгрунтував такі ідеї підготовки вчителів: вивчення в курсах педагогіки й методики шкільних підручників; проведення пробних i залікових уроків; проведення позакласної роботи 3 учнями; колективний аналіз уроків практиканта; узагальнення практикантом передового досвіду вчителів базової школи; узагальнення практикантом особистого досвіду, накопиченого упродовж педагогічної практики; зв'язок педагогічного навчального закладу з випускниками; систематичне вивчення новинок педагогічної літератури, рецензування окремих публікацій (Ельницкий, 1908). Актуальною вважаємо й до сьогодні думку педагога про те, що вивчення педагогічних дисциплін сприяє розвитку самоспостреження i самовдосконалення, розумної любові до дітей, формуванню професійного ставлення до явищ оточуючої дійсності (там само).

Досить інформативними, приміром, щодо організації діяльності другокласних церковних учительських шкіл $є$ низка публікацій у журналі за 1909 р.: стаття доглядача церковнопарафіяльних шкіл Київської митрополії М. Бєлогорського «Общежития при второклассных школах Киевской епархии» (Белогорский, 1909) та стаття Н. Луппова (ініціали російською мовою автори) «Второклассные церковныя учительские школы в первое десятилетие своего существования (1896-1906 гг.)» (Луппов, 1909). Зокрема, в статті Н. Луппова повідомлялося, що «Духовне відомство почало влаштовувати другокласні школи відповідно до рішення Державної Думи від 5 червня 1895 р. Їхнім завданням була підготовка учителів для шкіл грамоти. До 1907 року таких шкіл в Російській імперії було відкрито 426 (Луппов, 1909, с.30). А завдяки статті М. Бєлогорського можемо реально уявити режим проживання учнів в гуртожитках, який був майже однаковим в усіх школах: «О 7-й год. ранку учні вставали, о 7.30 год. здійснювали ранішню молитву, о 8 год. снідали, а 38.30 год. до 13.10 відбувалися уроки. О 15.00 учні обідали i проводили вільний час у дворі. О 17.00 розпочиналися вечірні заняття, які тривали до восьмої години вечора. Потім вечеряли і до 21.30 або продовжували виконувати домашні завдання, або читали книги. Потім була вечірня молитва і читалось «Життіє денного святого». О 23 годині учні лягали спати. Такий розпорядок міг бути змінений тільки напередодні свят та вихідних днів, коли учні по обіді готувалися до читання та співу в місцевому храмі» (Белогорский, 1909, с.18).

Методичний характер публікацій підтверджують, приміром, стаття, підписана ініціалами І. П. - «Методика квадратных и кубических мер» у № 2 за 1913 p. (І. П., 1913); відгук про значення для учителів появи нового методичного журналу «Родной язык в школе», вміщений у четвертому номері журналу «Западно-русская начальная школа» за 1916 рік (Западно-русская начальная школа, 1916). 
Про систему організації виховного процесу можна зробити висновки, проаналізувавши статті, присвячені цьому питанню. Наприклад, у № 2 за 1905 p. журналу «Западно-русская начальная школа» вміщено підбірку заміток учителів церковнопарафіяльних шкіл щодо особливості застосування покарань у школі. Зокрема, вчителька 3. Сатурнова у публікації «Как установить дисциплину, чтобы избежать в школе наказаний» зазначала: «Я даю своим ученикам в классе полную волю, они никогда не чувствуют себя стесненными никакими «установленными правилами», как это бывает во многих других сельских школах. Мои ребятишки свободно встают со своих мест, когда им это нужно, свободно обращаются ко мне со своими вопросами, но, конечно, с вопросами дельными, не пустыми; говорят мне о своих детских нуждах, рассказывают о своей семейной жизни; выходят из класса даже во время школьных занятий, когда им это необходимо. Наконец, могут даже говорить между собою, но негромко и в случае необходимости» (Сатурнова, 1905). Хоча інколи в класі бували такі ситуації, коли учні «и пикнуть не смеют, а не то, что разговаривать или подсказать» (там само).

Своєю чергою, аналіз замітки вчителя Київської митрополії Г. Лобачевського «Из наблюдений в народной школе» у цьому ж числі журналу дає змогу припустити, що в церковнопарафіяльних школах, на відміну від міністерських, тілесні покарання застосовувалися вкрай рідко, навіть батьки іноді скаржилися на відсутність або нестачу покарань у школі: «послышались недовольные голоса родителей, дети которых приняты в школу. «Какое это ученье у нас теперь, что никого в школе не наказывают?» слышалось с одной стороны. «Не без того, - доносилось с другой стороны, чтобы кто не поленился, а еще и на коленки никого не поставили... Вы же, пожалуйста, хорошенько учите моего сына - нередко просили учительницу заботливые родители - и на колени его ставьте, как следует, чтобы слушался» (Лобачевский, 1905).

В журналі «Западно-русская начальная школа» друкувалися статті, присвячені особистості вчителя, його кваліфікації, і що, на нашу думку, дуже важливо, статті про проблеми, які виникали у вчителів церковнопарафіяльних шкіл. Приміром, у статті «Причины, ослабляющие энергию сельских учителей», вміщеній у № 7 за 1906 р., мова йшла про психологічні чинники, які зумовлюють виснаження вчителя i гасять у ньому бажання працювати (Причины, ослабляющие энергию сельских учителей, 1906).

Достатньо насиченими на інформацію, що стосується антисанітарії та хвороби, є публікації в журналі стосовно умов навчання учнів та роботи вчителів. Журнал «Западно-русская начальная школа» здійснював ще й просвітницьку функцію, тому що саме вчителі часто були єдиними, хто дотримувався гігієни й закликав до цього селян. Це підтверджують публікації, у яких давалися поради вчителям 3 дотримання гігієни, як-то стаття 3. Покровської «Гигиенические советы школьному учителю», у якій авторка описувала конфлікти вчителя 3 батьками хворих дітей, які «не признают заразительности тех или других болезней и не верят тому, что существуют такие болезни, которые могут переходить по неизвестным причинам от одного человека к другому» та відправляють хворих дітей до школи (Покровская, 1906).

Висновки і перспективи подальших розвідок. Отже, цілісний аналіз змісту журналу «Западно-русская начальная школа» дає змогу зробити 
висновок, що часопис був своєрідною енциклопедією, навчально-методичним посібником, трибуною обміну досвідом творчих вчителів церковнопарафіяльних шкіл регіону початку XX ст.

У журналі друкувалися документи Св. Синоду, урядові розпорядження, що стосувалися сфери освіти, розпорядження єпархіальних училищних рад i їх роз'яснення, звіти про стан церковнопарафіяльних шкіл західноросійських єпархій, загальні педагогічні й методичні статті, що переважно стосувалися програм початкових і вчительських шкіл; повчальні статті, нариси й розповіді про внутрішнє життя школи, про позашкільну діяльність учителів, про участь школярів у богослужіннях, паломництвах, про заняття ремеслами й рукоділлям; матеріали з позашкільної освіти, про шкільні бібліотеки, вечірні і недільні класи для дорослих, читання для народу; огляди й рецензії видань 3 педагогіки. У якості додатків друкувалися документи з'їзду училищного ради (1907), звіти про стан церковнопарафіяльних шкіл Київської єпархії (19121917)

У публікаціях часопису відображені погляди вчених, письменників, суспільних діячів, учителів на розвиток початкової освіти. Незважаючи на відмінність у підходах до оцінки церковно-шкільної справи й певну упередженість в цих оцінках, публікації журналу містять велику кількість фактичного матеріалу про різноманітні аспекти діяльності початкових шкіл досліджуваного періоду.

Отже, журнал «Западно-русская начальная школа» $є$ цінним джерелом вивчення історії початкової освіти початку XX ст., інформативною ілюстрацією процесу розвитку регіональної початкової школи в контексті суспільно-культурного життя на українських землях.

Зміст номерів журналу «Западно-русская начальная школа» за майже сімнадцятирічну історію його існування, на сьогодні ще потребує глибокого й неупередженого вивчення на основі нових дослідницьких підходів, що вважаємо перспективою подальших наукових розвідок.

\section{СПИСОК ВИКОРИСТАНИХ ДЖЕРЕЛ:}

Побірченко, Н. (2010). Педагогічна наука на сторінках журналу «Советская педагогіка» (1937-1991) : бібліогр. покажч. Умань : Жовтий. 323 с

Панасенко, Е. (2001). Ідеал учителя у вітчизняній педагогічній журналістиці другої половини XIX- початку XX cm. Кандидат педагогічних наук. Слов'янськ. Донбаський педагогічний університет. $250 \mathrm{c}$.

Пугач, А. (2008). Проблеми підготовки вчителя до професійної діяльності в украӥнській педагогічній періодиџі (20-ті - початок 30-х років XX cm.). Кандидат педагогічних наук. Київ. Інститут педагогіки АПН України. 20 с.

Лобода, С. (2010). Педагогічна творчість учителя на шиальтах вітчизняної преси ХХ століття: протистояння ідей : монографія. Луганськ : Вид-во ДЗ «ЛНУ імені Тараса Шевченка». 504 с.

Бричок, С. (2013). Журнал «Церковно-приходская школа» як історикопедагогічне джерело вивчення діяльності церковнопарафіяльних шкіл (кінець XIX початок ХХ ст.). Педагогічний дискурс. Вип. 15. с. 92-97.

Шелюк, Г. (2015). Роль і місце журналу «Церковно-приходская школа» в організації навчально-виховного процесу початкових шкіл духовного відомства Волині (кінець XIX - початок XX ст.). Освіта крізь призму мікроісторії: заклади освіти, особистості, навчальна література, листування. Матеріали 
Всеукраӥнської науково-практичної конференції 22 жовт. 2015 p. Київ: Педагогічний університет ім. Б. Грінченка, с.147-157.

Перерва, В. (2014). Церковні школи в Украӥні (кінецьь XVIII - поч. XX cm.): забутий світ. Біла Церква: Видавець О. В. Пшонківський. Том I. Загальна частина. $576 \mathrm{c}$.

Троцкий, А. (2013). Православная энциклопедия. Режим доступа: http://www.pravenc.ru/text/182583.html [Дата звернення 21.03.2019]

Трошин, А. (1909). Журнал «Западно-русская начальная школа». Ист. очерк развития иерк. икол за истекшее 25-летие: (1884-1909 г2.): [Сб. ст.]. СПб. с. 622624.

Отчет о состоянии церковноприходских школ за 1912-1913 учебный год. (1915). Западно-русская начальная школа. № 2. с. 120.

Ельницкий, К. (1908). К вопросу о преподавании педагогики. Западно-русская начальная школа. Ежемесячный педагогический журнал. № 6. С.13-16.

Белогорский, Н. (1909). Общежития при второклассных школах Киевской епархии. Западно-Русская начальная школа. №2. Февраль. с. 16-24.

Луппов, Н. (1909). Второклассные церковныя учительские школы в первое десятилетие своего существования (1896-1906 гг.). Западно-Русская начальная школа. №1. Январь. с. 30-40.

I. П. (1913). Методика квадратных и кубических мер. Западно-русская начальная школа. № 2. с. 43-48.

Западно-русская начальная школа. (1916). № 4.

Сатурнова, 3. (1905). Как установить дисциплину, чтобы избежать в школе наказаний. Западно-русская начальная школа. № 2. с. 93.

Лобачевский, Г. (1905). Из наблюдений в народной школе. Западно-русская начальная школа. № 2. с. 104-105.

Причины, ослабляющие энергию сельских учителей, (1906). Западно-русская начальная школа. № 7. с. 276.

Покровская, 3. (1906). Гигиенические советы школьному учителю. Западнорусская начальная школа. № 6. с. 298.

\section{REFERENCES:}

Pobirchenko, N. (2010). Pedahohichna nauka na storinkakh zhurnalu "Sovetskaia pedahohyka" (1937-1991) [Pedagogical Science on the Pages of the Journal "Soviet Pedagogy" (1937 - 1991]: bibliohr. pokazhch. Uman : Zhovtyi. 323 s. [in Ukrainian]

Panasenko, E. (2001). Ideal uchytelia u vitchyznianii pedahohichnii zhurnalistytsi druhoi polovyny XIX - pochatku XX st. [The Ideal of a Teacher in the National Pedagogical Journalism of the Second Half of the 19th and the Beginning of the 20th Century]. Kandydat pedahohichnykh nauk. Sloviansk. Donbaskyi pedahohichnyi universytet. $250 \mathrm{~s}$. [in Ukrainian]

Puhach, A. (2008). Problemy pidhotovky vchytelia do profesiinoi diialnosti $v$ ukrainskii pedahohichnii periodytsi (20-ti - pochatok 30-kh rokiv XX st.). [Problems of Teacher Training for Professional Activity in Ukrainian Pedagogical Periodicals (20's early 30's Years of the 20th Century)]. Kandydat pedahohichnykh nauk. Kyiv. Instytut pedahohiky APN Ukrainy. $20 \mathrm{~s}$. [in Ukrainian]

Loboda, S. (2010). Pedahohichna tvorchist uchytelia na shpaltakh vitchyznianoi presy KhKh stolittia: protystoiannia idei: monohrafiia. [Pedagogical Work of the Teacher on the Pages of the National Press of the 20th Century: Confrontation of Ideas: monograph]: Luhansk : Vyd-vo DZ "LNU imeni Tarasa Shevchenka". 504 s. [in Ukrainian]

Brychok, S. (2013). Zhurnal "Tserkovno-prykhodskaia shkola" yak istorykopedahohichne dzherelo vyvchennia diialnosti tserkovnoparafiialnykh shkil (kinets XIX - 
pochatok XX st.). [Journal "Church Parish School" as a Historical and Pedagogical Source for the Study of Church Parish Schools (the end of the 19th and the beginning of the 20th Century)]. Pedahohichnyi dyskurs. Vyp. 15. s. 92-97. [in Ukrainian]

Sheliuk, H. (2015). Rol i mistse zhurnalu "Tserkovno-prykhodskaia shkola" v orhanizatsii navchalno-vykhovnoho protsesu pochatkovykh shkil dukhovnoho vidomstva Volyni (kinets XIX - pochatok XX st.). [The Role and Place of the journal "Church Parish School" in the Organization of the Educational Process of the Primary Schools of the Spiritual Department of Volyn (the end of the 19th - the beginning of the 20th Century)]. Osvita kriz pryzmu mikroistorii: zaklady osvity, osobystosti, navchalna literatura, lystuvannia. Materialy Vseukrainskoi naukovo-praktychnoi konferentsii 22 zhovt. 2015 r. Kyiv: Pedahohichnyi universytet im. B. Hrinchenka, s.147-157. [in Ukrainian]

Pererva, V. (2014). Tserkovni shkoly v Ukraini (kinets XVIII - poch. XX st.): zabutyi svit. [Church Schools in Ukraine (the end of the 18th - the beginning of 20th century): forgotten world]. Bila Tserkva: Vydavets O. V. Pshonkivskyi. Tom I. Zahalna chastyna. $576 \mathrm{~s}$. [in Ukrainian]

Trotskiy. A. (2013). Pravoslavnaya entsiklopediya. [Orthodox encyclopedia] Rezhim dostupa: http://www.pravenc.ru/text/182583.html [Data obrashcheniya 21.03.2019]. [in Russian]

Troshyn. A. (1909). Zhurnal "Zapadno-russkaya nachalnaya shkola" [Journal "West Russian Primary School"]. Ist. ocherk razvitiya tserk. shkol za isteksheye 25-letiye: (1884-1909 gg.): [Sb. st.]. SPb. s. 622-624. [in Russian]

Otchet o sostoyanii tserkovnoprikhodskikh shkol za 1912-1913 uchebnyi god. (1915). [Report on the State of Parochial Schools for the 1912-1913 School Year]. Zapadno-russkaya nachalnaya shkola. No 2. s. 120. [in Russian]

Elnitskiy. K. (1908). K voprosu o prepodavanii pedagogiki. Zapadno-russkaya nachalnaya shkola. [On the Issue of Teaching Pedagogy]. Ezhemesyachnyy pedagogicheskiy zhurnal. No 6. S.13-16. [in Russian]

Belogorskiy. N. (1909). Obshchezhitiya pri vtoroklassnykh shkolakh Kiyevskoy eparkhii. [Hostels at Second-class Schools of the Kiev Diocese]. Zapadno-Russkaya nachalnaya shkola. No 2. Fevral. s. 16-24. [in Russian]

Luppov. N. (1909). Vtoroklassnyye tserkovnyya uchitelskiye shkoly v pervoye desyatiletiye svoyego sushchestvovaniya (1896-1906 gg.). [Second-class Church Teachers' Schools in the First Decade of Their Existence (1896-1906)]. ZapadnoRusskaya nachalnaya shkola. No 1. Yanvar. s. 30-40. [in Russian]

I. P. (1913). Metodika kvadratnykh i kubicheskikh mer. [Methods of square and cubic measures.]. Zapadno-russkaya nachalnaya shkola. No 2. s. 43-48. [in Russian]

Zapadno-russkaya nachalnaya shkola. [West Russian Primary School] (1916). No 4. [in Russian]

Saturnova. Z. (1905). Kak ustanovit distsiplinu. chtoby izbezhat v shkole nakazaniy. [How to Fix Discipline to Avoid Punishment at School]. Zapadno-russkaya nachalnaya shkola. No 2. s. 93. [in Russian]

Lobachevskiy. G. (1905). Iz nablyudeniy v narodnoy shkole. [From Observations in Russian School]. Zapadno-russkaya nachalnaya shkola. No 2. s. 104-105. [in Russian]

Prichiny. oslablyayushchiye energiyu selskikh uchiteley. (1906). [Causes that Weaken the Energy of Rural Teachers]. Zapadno-russkaya nachalnaya shkola. No 7. s. 276. [in Russian]

Pokrovskaya. Z. (1906). Gigiyenicheskiye sovety shkolnomu uchitelyu. [Hygiene Tips for School Teacher]. Zapadno-russkaya nachalnaya shkola. No 6. s. 298 [in Russian] 


\title{
JOURNAL "WESTERN RUSSIAN PRIMARY SCHOOL" AS A SOURCE OF STUDYING THE ACTIVITIES OF REGIONAL PRIMARY SCHOOLS AT THE BEGINNING OF THE 20TH CENTURY
}

\author{
Brychok Svitlana \\ Candidate of Pedagogical Sciences, \\ Associate Professor, Associate Professor \\ at the Department of Primary Education Pedagogy, \\ Rivne State University of the Humanities, \\ Rivne, Ukraine \\ ORCID: 0000-0001-8508-8395, \\ e-mail: brychok.zd@gmail.com
}

\author{
Sheliuk Halyna \\ Lecture at the Department of Theory and Methodology of Education, \\ Rivne, Ukraine \\ ORCID: 0000-0001-7648-3166, \\ e-mail: galina_rustle@ukr.net
}

\begin{abstract}
In the article, based on a holistic analysis of the contents of the magazine "WestRussian Primary School" (1906-1917), the authors proved that the journal was a kind of encyclopedia, a teaching manual, a platform for the exchange of experience of creative teachers of parochial schools at the beginning of the twentieth century. The journal printed the documents of the Holy Synod, government orders related to the spheres of education, the orders of the diocesan councils and their explanations, reports on the status of church parish schools of the western dioceses, general pedagogical and methodological articles, which mainly concerned programs of elementary and teacher schools; instructive articles, essays and stories about the inner life of the school, about the extracurricular activity of teachers, about the participation of schoolchildren in worship, pilgrimages, and the pursuit of crafts and crafts; extracurricular education, school libraries, evening classes and Sunday classes for adults, reading for the people; reviews of editions on pedagogy. As applications, the documents of the congress of the school council (1907), reports on the status of church parish schools of the Kyiv diocese (1912-1917) were printed.

The publications of the magazine reflected the views of scholars, writers, public figures, and teachers on the development of elementary education. Despite the difference in approaches to the assessment of church-school affairs and some bias in these assessments, journal publications contain a large amount of factual material on the various aspects of the activity of elementary schools during the period under study.

It was proved that the journal "West-Russian Primary School" is a valuable source for studying the history of elementary education at the beginning of the 20th century, an informative illustration of the process of development of a regional elementary school in the context of social and cultural life on Ukrainian lands.
\end{abstract}

Key words: journal "West-Russian primary school", historical-pedagogical source, primary schools, teacher, church parish schools.

Стаття надійшла до редакиї 25.04.2019 p. 